\title{
ENERGY LOSSES IN FOWL AND DUCK EGGS DURING INCUBATION
}

\author{
A. HOLUB, E. PONIŽILOVÁ and E. BARANYIOVÁ ${ }^{1}$ \\ ${ }^{1}$ Department of Biochemistry, \\ University of Veterinary and Pharmaceutical Sciences, 61242 Brno
}

Received January 28, 1994

\begin{abstract}
Holub A., E. Ponížilová, E. Baranyiová: Energy Losses in Fowl and Duck Eggs during Incubation. Acta vet. Brno, 63, 1994: 115-120.

Energy (gross energy, GE) transfer based on chemical composition was studied in 80 layer (White Leghorn, WL) eggs, in 80 broiler (New Hampshire, NH) eggs between days 1 and 20 of incubation, and in 40 White Beijing duck eggs between days 1 and 25 .

Our data indicate that at the beginning of incubation, both NH and duck eggs contained substantially more energy $(450 \pm 18 \mathrm{~kJ}$ and $614 \pm 18 \mathrm{~kJ}$, respectively) than WL eggs $(359 \pm 15 \mathrm{~kJ})$. In the course of incubation, $30.8 \%$ of available energy was utilized by $\mathrm{WL}, 33.9 \%$ by $\mathrm{NH}$, and $19.9 \%$ by Beijing ducks. Thus the highest incubation efficiency was found in ducks. This is also indicated by their incubation power that reached only $45.5 \mathrm{~mW}$. It was higher in WL and NH (63.9 and $88.3 \mathrm{~mW}$, respectively). Similar results were obtained when this power was calculated for the initial and metabolic egg mass. Also the formation and functioning of the new individual's tissues (including the embryonic membranes and fluids) required the smallest GE amount in ducks $\left(2.39 \mathrm{~kJ}^{-1}\right)$, whereas in WL it increased to $3.66 \mathrm{~kJ} . \mathrm{g}^{-1}$, and in NH to $4.12 \mathrm{~kJ} . \mathrm{g}^{-1}$. The transfer of one J of GE from the eggs into tissues of embryos (without membranes anf meconium) required $0.95 \mathrm{~J}$ in WL, $0.87 \mathrm{~J} \mathrm{in} \mathrm{NH}$, and only $0.54 \mathrm{~J}$ in ducks. These energy transfer processes did not become significant until the last 9 (in fowl) or 10 (in ducks) days of incubation. The almost exclusive energy source during incubation were lipids. Protein energy amount did not decrease significantly except for WL.

These experimental data confirm the older ones only in part. Some interspecies differences, originating also from the fact that incubation of ducks lasts longer, are smaller than intraspecies differences, those between layer and broiler type of chicks. These facts show that the incubation energy transfer in avian species is not only variable but also adaptable.
\end{abstract}

Incubation, loss of macronutrients, interspecies and intraspecies differences, incubation power

Embryonic development of birds has been an attractive object of study for several decades. However, its interpretation in physiological terms has only been approached more recently. This is based on the fact that except for oxygen the avian egg contains all components necessary for the development of embryo, including the source of energy. In fowl eggs, there is 293 to $455 \mathrm{~kJ}$ of energy available (Tangl 1903, Tangl and von Mituch 1908, Brody 1945, Romanoff and Romanoff 1949, Svensson 1964, Sibbald 1979, Ricklefs 1987, Ar et al. 1987, Vleck and Vleck 1987). From extrapolated data on mass and chemical composition of duck eggs (Plimmer and Lowndes 1924, Grossfeld 1938) a content of 541 to $560 \mathrm{~kJ}$ energy may be calculated. Based on newer data, it is 427 to $611 \mathrm{~kJ}$ (Vleck and Vleck 1987). This gross energy (GE) is in part $(57.0 \pm 7.0 \%)$ transformed to tissue energy of the growing embryo (Hoyt and Rahn 1980, Sotherland and Rahn 1987). Another portion of this energy, except for a small amount bound in extraembryonic membranes (8.3\%) (Ar et al. 1987), becomes a potential energy source for the early postembryonic life. For growth of embryonic tissues, their metabolism and muscular activity, especially at hatching (Hoyt 1987), 34.7\% of energy is utilized. In other words, to build $1 \mathrm{~g}$ of dry matter, the individual utilizes $15.4 \mathrm{~kJ}$ of energy.

In this context, surprisingly few data are available on energy flow during the individual incubation phases. Likewise, species, breed and type differences in energy metabolism during hatching in domesticated avian species have not been studied in detail. Therefore, after a preliminary presentation of a part of our results (Holub and Baranyiová 1991, Holub et al. 1991) we decided to complete these data and present their new interpretation.

\section{Materials and Methods}

Data on layer (White Leghorn) and broiler (New Hampshire) eggs were obtained on days 1,3,11, 15 and 20 of incubation. At each age, eight eggs were analyzed (Wu 1964). They were incubated at $38-38.5^{\circ} \mathrm{C}$ in the first week of incubation, at $38.5-39.0^{\circ} \mathrm{C}$ in the second, and at $39.0-39.5^{\circ} \mathrm{C}$ in the third week, at relative humidity of 60 to $70 \%$. The eggs were turned at 8-h intervals, and candled on days 7 and 15. For chemical analysis, the eggs were weighed, and eggshells, membranes, albumen, egg yolk, embryos and their embryonic membranes with fluids were separated. These components were then individually weighed and dried to constant mass at 90 to $95^{\circ} \mathrm{C}$. In these samples, lipid (Montemurro and Stevenson 1960) and total nitrogen (Conway 1957) were determined in parallel. Protein content was calculated ( $\mathrm{N}$ 6.25). 
In the experiments with ducks (Beijing breed), groups of ten eggs each were analyzed on days 1, 15, 20 and 25 of incubation. They were kept at $37.5^{\circ} \mathrm{C}$ (until day 19 , and at $38.5^{\circ} \mathrm{C}$ (until day 25), at relative humidity of 60 to $70 \%$. The eggs were candled on day 16. Chemical analyses were carried out as mentioned above (Ponížilová 1970).

The amount of GE in the individual components of the eggs, embryos and yolk sacs was calculated from the pro-

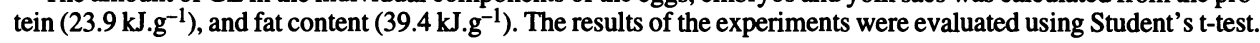

\section{Results}

At the beginning of incubation, the GE content in eggs of both fowl breeds and ducks differed significantly $(P<0.01)$, the lowest energy content being in WL eggs. In $\mathrm{NH}$ it was 25 and in ducks $71 \%$ more (Table 1). These differences were due not only to larger mass (WL $55.7 \pm 0.5 \mathrm{~g}, \mathrm{NH} 66.1 \pm 1.2 \mathrm{~g}$, and ducks $88.8 \pm 2.0 \mathrm{~g}$ ) but also to higher energy density of $\mathrm{NH}$

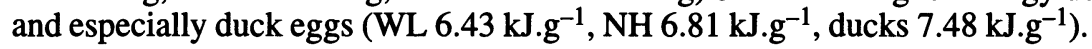

Table 1

Energy density (GE) of layer and broiler chicks eggs, and Beijing duck eggs in the course of incubation (kJ)

\begin{tabular}{|c|c|c|c|}
\hline $\begin{array}{c}\text { Day of } \\
\text { incubation }\end{array}$ & WL & NH & Ducks \\
\hline $\begin{array}{c}1 \\
3 \\
11 \\
15 \\
20 \\
25\end{array}$ & $\begin{array}{c}359 \pm 15 \\
338 \pm 21 \\
349 \pm 17 \\
306 \pm 29 \\
248 \pm 18 \\
-\end{array}$ & $\begin{array}{c}450 \pm 16 \\
416 \pm 14 \\
425 \pm 18 \\
369 \pm 32 \\
297 \pm 38 \\
-\end{array}$ & $\begin{array}{c}614 \pm 18 \\
- \\
- \\
630 \pm 30 \\
572 \pm 31 \\
516 \pm 37\end{array}$ \\
\hline
\end{tabular}

In the course of incubation, the energy amount decreased in all eggs so that close to its end (in the fowl, day 20, and in ducks day 25) there was 69.2, 66.1 and 84.1\% energy left, respectively. In other words, $110 \pm 6,153 \pm 16$ and $98 \pm 10 \mathrm{~kJ}$, i. e. $30.8,33.9$ and $15.9 \%$ of energy was utilized. Its greatest decrease was observed in NH eggs, smallest in duck eggs. It was also unevenly distributed in the course of incubation, and did not become significant until its second half as evident also from the difference between daily losses of GE during the entire incubation and its second half (Fig. 1). This trend was also evident in relative decrease of GE calculated for actual and metabolic $\left(\mathrm{kg}^{-0.75}\right)$ egg mass (Fig. 2 and 3).

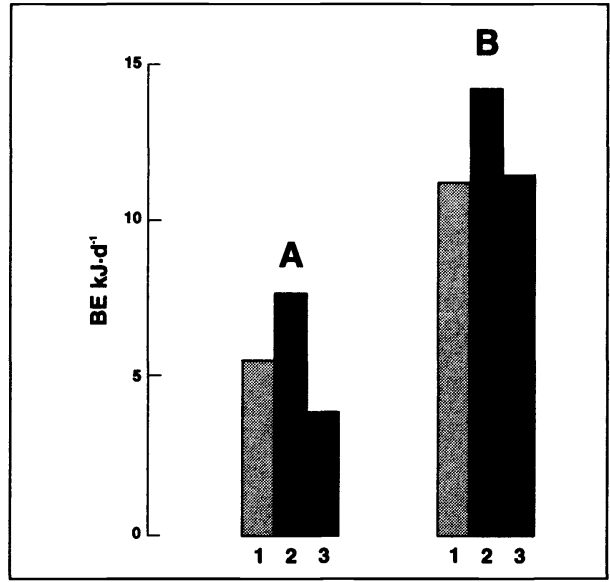

Fig. 1. Average daily loss of energy (GE) in incubated eggs of WL (1), NH (2) and ducks (3), A (in the fowl day 1 to 20 , in ducks day 1 to 25 ), B (in the fowl day 11 to 20 of incubation, in ducks day 15 to 25 of incubation)

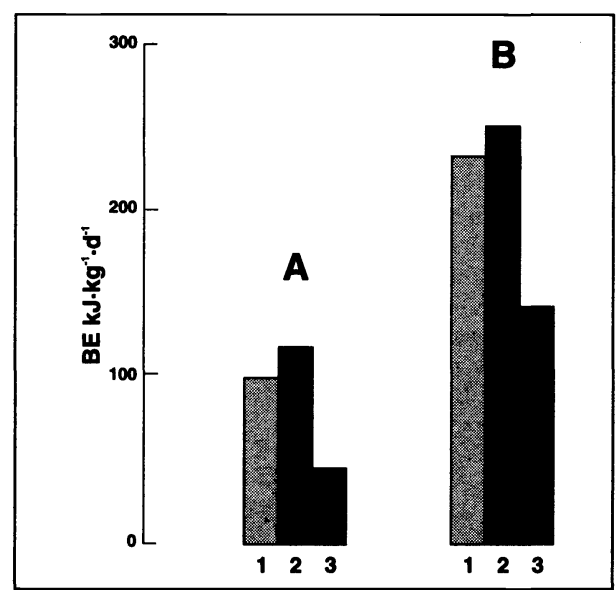

Fig. 2. Average relative daily loss of energy (GE) in incubated eggs per initial egg mass of WL (1), NH (2) and ducks (3), A (in the fowl day 1 to 20 , in ducks day 1 to 25 of incubation), B (in the fowl day 11 to 20 , in ducks day 15 to 25 of incubation) 


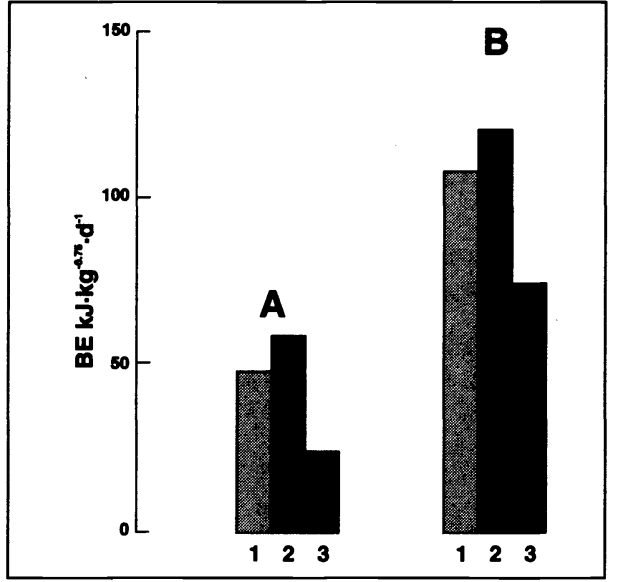

Fig. 3. Average relative daily loss of energy (GE) in incubated eggs per initial metabolic egg mass of WL (1), NH (2) and ducks (3), A (in the fowl day 1 to 20 , in ducks day 1 to 25 ), $\mathrm{B}$ ( in the fowl day 11 to 20 , in ducks day 15 to 25 ) pectively). Yet more protein energy was available in ducks: on day $1(\mathrm{P}<0.01)$, on day $15(\mathrm{P}<0.05)$, and also on day $20(\mathrm{P}<0.01)$. In all experimental individuals, its amount decreased in the course of incubation, however, significantly only in WL between days 1 and $20(P<0.05)$ (Tab. 6).

Table 2

Average incubation power of layer and broiler chicks, and Beijing ducks ( $\mathrm{mW}$ )

\begin{tabular}{|c|c|c|c|}
\hline & WL & NH & Ducks \\
\hline in the entire incubation ${ }^{1}$ & $64,2 \pm 3,7$ & $88,5 \pm 7,3$ & $45,4 \pm 4,6$ \\
\hline in the second half of incubation ${ }^{2}$ & $129,9 \pm 6,1$ & $164,6 \pm 10,9$ & $136,6 \pm 13,6$ \\
\hline
\end{tabular}

Note: ${ }^{1}$ in the fowl days 1 to 20 , in ducks days 1 to $25:{ }^{2}$ in the fowl days 11 to 20 , in ducks days 15 to 25

Table 3

Average relative incubation power (per egg mass) in layer and broiler eggs, and Beijing duck eggs (W.kg-1)

\begin{tabular}{|c|c|c|c|}
\hline & WL & NH & Ducks \\
\hline In the entire incubation ${ }^{1}$ & $1,15 \pm 0,07$ & $1,34 \pm 0,11$ & $0,51 \pm 0,05$ \\
\hline In the second half of incubation ${ }^{2}$ & $2,67 \pm 0,13$ & $2,86 \pm 0,19$ & $1,60 \pm 0,16$ \\
\hline
\end{tabular}

Note: For ${ }^{1}$ and ${ }^{2}$, see Table 2

Table 4

Average relative incubation power (per metabolic mass of eges) in layer and broiler eggs, and in Beijing ducks (W.kg ${ }^{0.75}$ )

\begin{tabular}{|c|c|c|c|}
\hline $\begin{array}{l}\text { Day of } \\
\text { incubation }\end{array}$ & WL & NH & Ducks \\
\hline $\begin{array}{l}\text { In the entire } \\
\text { incubation } 1\end{array}$ & $0.56 \pm 0.03$ & $0.68 \pm 0.06$ & $0.28 \pm 0.03$ \\
\hline $\begin{array}{l}\text { In the second half } \\
\text { of incubation } 2\end{array}$ & $1.25 \pm 0.06$ & $1.40 \pm 0.09$ & $0.87 \pm 0.06$ \\
\hline
\end{tabular}

Note: For 1 and 2, see Tab. 2 
Table 5

Energy (GE) content in lipids of layer and broiler eggs, and in Beijing duck eggs during incubation (kJ)

\begin{tabular}{|cccc|}
\hline $\begin{array}{l}\text { Day of } \\
\text { incubation }\end{array}$ & WL & Fowl & NH \\
\hline 1 & $217 \pm 9$ & $272 \pm 9$ \\
3 & $197 \pm 14$ & $252 \pm 8$ & $257 \pm 9$ \\
11 & $195 \pm 8$ & $207 \pm 14$ & $151 \pm 19$ \\
15 & $175 \pm 10$ & - & $406 \pm 10$ \\
20 & $136 \pm 9$ & - & $363 \pm 18$ \\
25 & - & $299 \pm 24$ \\
\hline
\end{tabular}

Table 6

Energy content (GE) in proteins of layer and broiler eggs, and in Beijing duck eggs during incubation (kJ)

\begin{tabular}{|cccc|}
\hline $\begin{array}{l}\text { Day of } \\
\text { incubation }\end{array}$ & WL & Fowl & NH \\
\hline 1 & $142 \pm 6$ & $178 \pm 7$ & $209 \pm 8$ \\
3 & $142 \pm 8$ & $164 \pm 5$ & $169 \pm 9$ \\
11 & $153 \pm 8$ & $163 \pm 19$ & $21 \pm 11$ \\
15 & $132 \pm 19$ & $147 \pm 19$ \\
25 & $112 \pm 9$ & - & $209 \pm 13$ \\
\hline
\end{tabular}

Formation and functioning of a mass unit of the new individuals, including their extraembyonic membranes, yolk sac and transfer of fluids presented the highest GE cost in NH

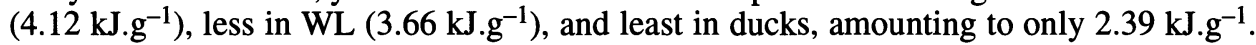
From each $\mathrm{J}$ of energy stored in eggs, $0.95 \mathrm{~J}$ was transferred into the embryonic bodies (without fetal membranes and meconium) in WL, 0.87 in NH, and 0.54 in ducks. This transfer was mostly into their body protein, $56.1 \%$ in WL, $54.6 \%$ in NH, and $53.3 \%$ in ducks.

\section{Discussion}

The egg size, length of incubation and functional maturity of hatchlings belong to determinants of energetic efficiency of the incubation process. This incubation efficiency shows only slight variations among avian species (Vleck et al. 1979, 1980). However, when the energy of substances that enter intact the yolk sac of hatchlings, is added to the energy of their bodies, the incubation efficiency of marine birds is $58 \%$ while that of domesticated fowl 73 to $76 \%$ (Ar et. al. 1987). Both altricial and precocial species belong to those with higher incubation efficiencies. Therefore it can be assumed that species, breed, or type differences indicate adaptation variability rather than differences in general and strategic trends in the incubation process. Energy losses during incubation mirror the energy efficiency of the process.

This topic has been mostly studied in domesticated avian species. In fowl, from $408 \mathrm{~kJ}$ utilized (Vleck and Vleck 1987), i. e. 23.4 and 21.6\%, respectively. In other words, the incubation efficiency is 76.6 or 62.0 to $65.3 \%$ (Tangl 1908, Tangl and von Mituch 1908, Brody 1945, Ar et al. 1987) in fowl, and 78.4\% in ducks (Vleck and Vleck 1987).

In our measurements, the GE losses were higher but those in ducks were lower than the above values. However, only few data from experiments carried out so far can be compared. Differences may be explained by different approaches and criteria, also by lack of uniformity in the experimental material used. Further, functional changes should be taken into account. These result from recent breeding procedures and aims. So, for example, in our experiments the incubation energetics of meat type chicks differed in some parameters more from layers than from ducks.

In the first half of incubation, the losses in energy amount were not significant in our experiments. They became more pronounced and significant only in the second half in agreement with data on direct and indirect calorimetry of fowl incubation (Romanoff and Roma- 
noff 1949, Romanoff 1960, Romijn and Lokhorst 1951, 1960, Freeman and Vince 1974).

Maximum incubation power of chicks is given as $130 \mathrm{~mW}$ (Tazawa et al. 1988). In our experiments such performance was observed in WL and ducks, and only in the second half of incubation; it was higher in NH. However, this comparison is not quite flawless as Tazawa et al. (1988) did specify neither the egg origin, nor their incubation phase to which the values were assigned. A remarkable observation, namely, that the relative incubation efficiency of decks wose embryos are developing in eggs richer in energy, is lower than in fowl, may serve as another stimulus for cmparative physiology of hatching.

\section{Úbytek energie ve vejcích kurů a kachen během inkubace}

V průběhu inkubace jsme u 80 vajec kurů nosných (LB) a masných (NH) (mezi 1. a 20. d) a u 40 vajec pekingských bílých kachen (mezi 1. a 25. d) určovali na základě chemického složení energetické (BE) změny. $Z$ provedených měření vyplývá:

$\mathrm{Na}$ začátku inkubace byla vejce $\mathrm{NH}(450 \pm 16 \mathrm{~kJ})$ na BE asi o čtvrtinu a kachen $(614 \pm 18$ $\mathrm{kJ})$ téměř o tři čtvrtiny bohatší než LB $(359 \pm 15 \mathrm{~kJ})$. V průběhu inkubace $\mathrm{z}$ ní bylo spotřebováno u LB 30,8, u NH 33,9 a u kachen 19,9\%. Největší energetickou efektivnost líhnutí tedy vykazovaly kachny. Je to patrno i z jejich inkubačního výkonu, který dosahoval jen $45,5 \mathrm{~mW}$; u LB a NH byl vyšši $(63,9$, prípadně $88,3 \mathrm{~mW})$. Obdobně tomu bylo i v prípadě, že byl kalkulován na počáteční hmotnost vajec, a to i na metabolickou. Též na formování a fungování tkání nového jedince (včetně extraembryonálních membrán a tekutin) spotřebovaly nejméně BE kachny, 2,39, zatímco LB 3,66 a NH 4,12 kJ.g ${ }^{-1}$. Na presun jednotky $\mathrm{BE} z$ vajec do tkání těl embryí (bez obalů a mekonia) se využilo u LB 0,95 , u NH 0,87 a u kachen jen $0,54{\mathrm{~J} . \mathrm{J}^{-1}}^{-}$.

Uvedené energetické procesy nabyly na průkaznosti teprve v posledních devíti (u kurů) či deseti ( $u$ kachen) dnech. Téměr výlučným inkubačním zdrojem BE byly tuky. $Z$ proteinů jí totiž, až na kury nosné, v průběhu líhnutí průkazně neubývalo.

Dosažené výsledky potvrzují starší údaje jen zčásti. Některé diference mezidruhové, podmíněné mimo jiné i tím, že líhnutí kachen trvá déle než kurů, jsou menší než nitrodruhové, mezi kury nosnými a masnými. Tyto skutečnosti svědčí o tom, že inkubační energetika je u ptákủ nejen variabilní, ale i adaptabilní.

\section{Убыль энергии в яйцах куриц и уток в ходе инкубации}

В ходе инкубации у 80 яиц куриц несушек (LB) и мясопродуктивных птиц (NH) (в промежутке 1 - 20 суток) и у 40 яиц пекинских белых уток (в интервале 1 - 25 суток) определяли на основе химического состава энергетические (BE) изменения.

Из проведенных измерений вытекает:

В начале инкубации яйца $\mathrm{NH}(450 \pm 16 \mathrm{~kJ})$ в BE приблизительно на одну четверть и яйца уток ( $614 \pm 18 \mathrm{~kJ})$ почти на три четверти богаче LB $(359 \pm 15 \mathrm{~kJ})$. В ходе инкубации из данного количества израсходовали LB 30,8, NH 33,9 и утки 19,9\%. Следовательно, самой большой эффективностъю инкубирования яиц отличались утки. Данное обстоятельство наглядно также в случае мощности инкубирования, достигаемой лишь 45,5 мBT; y LB. и NH больше (63,9, а также 88,3 мВт). Аналогично обстояло дело в случае расчета к первоначальной массе яиц, а именно в метаболическую. Также для формирования и функционирования тканей новой особи (включая внеэмбриональные мембраны и жидкости) расходовали меньше всех ВЕутки $-2,39$, между тем как LB 3,66 и NH 4,12 kJ. $\Gamma^{-1}$. Для перемещения единицы BE из яиц в ткани тела эмбрионов (без оболочки и мекония) использовали LB 0,95, NH 0,87 и утки лишь $0,54 \mathrm{~kJ}^{-1}$. 
Приведенные энергетические процессы стали доказательными только в течение последних девяти (у куриц) или десяти (утки) суток. Почти исключительным источником инкубации ВЕ стали жиры. Дело в том, что они из протеинов - за исключением несушек - в ходе инкубирования явно не исчезали.

Достигнутые результаты подтверждают более ранние данные лишь отчасти. Некоторые межвидовые расхождения, обусловленные, помимо прочего, также тем, что инкубирование яиц уток длится дольше, чем у куриц, гораздо меньше, чем расхождения внутри вида, между несушками и мясопродуктивными птицами. Данное обстоятельство свидетельствует о том, что инкубационная энергетика птиц не только отличается способностью к изменчивости, но и приспособляемости.

\section{References}

AR, A.-ARIELI, B.-BELINSKY, A.-YOM-TOV, Y.: Energy in avian eggs and hatchlings: Utilization and transfer. J. Exp. Zool., Suppl. 1, 1987: 151-164

BRODY, S.: Bioenergetics and growth. New York 1945

CONWAY, E. J.: Microdiffusion analysis and volumetric error. London 1957

FREEMAN, B. M. - VINCE, M. A.: Development of the avian embryo. London 1974

GROSSFELD, J.: Handbuch der Eierkunde. Berlin 1938

HOLUB, A.-BARANYIOVÁ, E.: Incubation and postincubation sources of energy in chickens. In: Sborník referátù 24. mezinárodní konference o fyziologii drúbeže. Bmo 1991. p. 154

HOLUB, A.-PONÍŻILOVÁ, E.-BARANYIOVÁ, E.: Incubation and postincubation sources of energy in ducks. In: Sborník referátú 24. mezinárodní konference o fyziologii drủbeže. Brno 1991.p. 152

HOYT, D. F.: A new model of avian embryonic metabolism. J. Exp. Zool., Suppl.1, 1987: 127-138

HOYT, D. F.-RAHN, H.: Respiration of avian embryo - A comparative analysis. Resp. Physiol., 39, 1980: 255-264

MONTEMURRO, D. G.-STEVENSON, A. F.: Survival and body composition of normal and hypothalamic obese rats in acute starvation. Amer. J. Physiol., 198, 1960: 757-761

PLIMMER, P. H.-LOWNDES, A.: The changes in the lime content of the hen's egg during development. Biochem. J., 18, 1924: 1168-1169

PONIŻILOVA, E.: Chemické a váhové změny inkubovaného kachního vejce a zárodku. Ph.D.Thesis. VF VŠZ, Brno 1970. 113 p.

RICKLEFS, R. E.: Comparative analysis of avian embryonic growth. J. Exp. Zool., Suppl., 1, 1987: 300-323

ROMANOFF, A. L.: The avian embryo. New York 1960

ROMANOFF, A. L.-ROMANOFF, A. J.: The avian egg. New York 1949

ROMIJN, C.-LOKHORST, W.: Foetal respiration in the hen. Physiol. Comp., 2, 1951: 187-197

ROMIJN, C.-LOKHORST, W.: Foetal heat production in the fowl. J. Physiol., 150, 1960: 230-249

SIBBALD, I. R.: The gross energy of avian eggs. Poultry Sci., 58, 1979: 404-409

SOTHERLAND, P. R.-RAHN, H.: On the composition of bird eggs. Condor, 89, 1987: 48-65

SVENSSON, S. A.: Composition and energy content of eggs, growing chicks and hens with some notes on preparation and methods of analysis. Lantbr. Högsk. Ann., 30, 1964: 405-422

TANGL, F.: Beiträge zur Energetik der Ontogenese. Pflügers Arch. Ges. Physiol., 93, 1903: 327-376

TANGL, F.-MITUCH, A. von: Beiträge zur Energetik der Ontogeneze. V. Mitteilung. Weitere Untersuchungen über die Entwicklungsarbeit und den Stoffumsatz im bebrütenen Hühnerei. Pflügers Arch. Ges. Physiol., 121, 1908: 437-458

TAZAWA, H.-WAKAYAMA, H.-TURNER, J. S.-PAGANELLI, C. V: Metabolic compensation for gradual cooling in developing chick embryos. Comp. Biochem. Physiol. A, 89, 1988: 125-129

VLECK, C. M.-HOYT, D. F.-VLECK, D.: Metabolism of avian embryo: Patterns in altricial and precocial birds. Physiol. Zool., 52, 1979: 363-377

VLECK, C. M.-VLECK, D.: Metabolism and energetics of avian embryo. J. Exp. Zool., Suppl. 1, 1987: 111-125

VLECK, C. M.-VLECK, D.-HOYT, D. F.: Patterns of metabolism and growth in avian embryos. Amer. Zool., 20, 1980: $405-416$

WU AN-KUO: Změny chemického složení vajec a kư̌at u plemene bílých leghornek a new-hampshire v inkubačním a postinkubačním údobí.Ph.D. Thesis, VF VŠZ Brno 1964.241 p. 